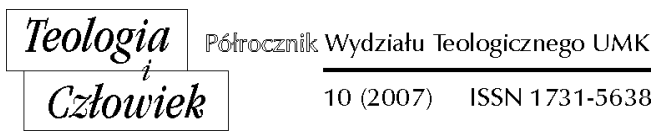

MARCIN ZIEMKOWSKI*

TORUŃ

\title{
„DEKLARACJA NA RZECZ JEDNOŚCl” POLSKIEGO NARODOWEGO KOŚCIOŁA KATOLICKIEGO I KOŚCIOŁA RZYMSKOKATOLICKIEGO W USA
}

Rok 2006 przyniósł doniosłe wydarzenie w trwającym od $1984 \mathrm{r}$. dialogu ekumenicznym pomiędzy wymienionymi w tytule Kościołami. Chodzi o podpisanie przez ich przedstawicieli w maju $2006 \mathrm{r}$. w miejscowości Fall River w USA, „Deklaracji na rzecz jedności”.

Początek relacji ekumenicznych pomiędzy Kościołem rzymskokatolickim a PNKK w USA rozpoczął się w 1966 r., gdy stojący wówczas na czele PNKK bp Leon Grochowski zwrócił się do biskupa rzymskokatolickiego w miejscowości Scranton, mateczniku PNKK, z propozycją nawiązania dialogu. Lata sześćdziesiąte minionego stulecia można określić mianem „nowego zesłania Ducha Świętego”, zarówno w Kościele rzymskokatolickim, po Vaticanum Secundum, jak i w PNKK w USA. Jego efektem był wzrost poczucia duchowej bliskości pomiędzy polskokatolikami a rzymskokatolikami w Stanach Zjednoczonych. Działo się tak pomimo bolesnej przeszłości związanej z powstaniem Polskiego Narodowego Kościoła Katolickiego w USA wśród polskich emigrantów na przełomie XIX i XX wieku.

* Mgr Marcin Ziemkowski jest asystentem w Zakładzie Polityki Społecznej Instytutu Socjologii UMK. 
Jak stwierdza Deklaracja, ówczesne kontrowersje dotyczyły głównie spraw administracyjnych, nie zaś doktrynalnych. Mimo to, zapoczątkowały one serię wydarzeń wiodących do podziału, który, jak bywało, dotykał członków tych samych rodzin.

Symbolicznym gestem na rzecz pojednania było nabożeństwo w polskokatolickiej katedrze pod wezwaniem św. Stanisława w Scranton w Pensylwanii, które odbyło się 15 lutego 1992 r. Przewodniczyli mu m.in. kardynał Edward Cassidy, ówczesny Przewodniczący Papieskiej Rady ds. Popierania Jedności Chrześcijan oraz biskup John Swantek stojący na czele Polskiego Narodowego Kościoła Katolickiego. Podczas nabożeństwa obydwie strony zwróciły się do siebie z prośbą o przebaczenie, a także zobowiązały się do działań na rzecz ostatecznego przezwyciężenia podziału. W pięć lat później, rzymskokatolicki biskup John Timlin, ówczesny współprzewodniczący dialogu pomiędzy Kościołami, w liście z okazji stulecia powstałego w 1897 r. PNKK, ponowił prośbę o przebaczenie.

W 1989 r. podsumowano pierwszy etap dialogu, który przyniósł porozumienie na temat siedmiu sakramentów. Stwierdzono wówczas, że pomimo pewnych różnic $\mathrm{w}$ ich sprawowaniu nie istnieją przeszkody doktrynalne uniemożliwiające dalsze zbliżenie obydwu wspólnot. Znalazło to odzwierciedlenie w decyzji kardynała Cassidy, który jako Przewodniczący Papieskiej Rady ds. Popierania Jedności Chrześcijan ogłosił w 1993 r., iż wierni PNKK w USA i Kanadzie mogą przystępować do sakramentów: pojednania, Komunii św. oraz namaszczenia chorych w Kościele rzymskokatolickim, jeśli występują o to z własnej woli, są właściwie dysponowani oraz nie są wykluczeni $\mathrm{z}$ możliwości przyjmowania sakramentów, zgodnie z zapisem paragrafu 3 kanonu 844 Kodeksu Prawa Kanonicznego.

W 1998 r. PNKK ogłosił wytyczne dotyczące przystępowania jego wiernych do sakramentów w Kościele rzymskokatolickim, którego członkowie z kolei mogą otrzymywać sakramenty w PNKK pod specjalnymi warunkami, opisanymi w par. 2 kanonu 844 Kodeksu Prawa Kanonicznego.

Wzajemne uznawanie sakramentów oraz, by tak rzec, „eklezjalności" obydwu Kościołów oznacza istnienie między nimi niepełnej wspólnoty sakramentalnej świadczącej o ich wyrazistym współuczestniczeniu w katolickiej tradycji.

Jak stwierdza „Deklaracja”, pożądana komunia pomiędzy PNKK a Kościołem rzymskokatolickim nie zakłada uniformizacji bądź wchłonięcia jednego Kościoła przez drugi, lecz stan, w którym obydwie tradycje wspólistnieją jako uprawnione wyrazy jednej, apostolskiej wiary. Należy ustalić, które elementy eklezjalnej rzeczywistości stanowią źródło podziału, 
które zaś są przejawem akceptowalnej różnorodności. Wątek ten podniósł Jan Paweł II w encyklice Ut Unum Sint z 1995 r., stwierdzając, że różnorodność taka nie jest przeszkodą dla jedności Kościoła, lecz przyczynia się do wypełnienia jego misji.

Pełna komunia pomiędzy PNKK a Kościołem rzymskokatolickim pozostaje jednak celem, którego realizacja wymagać będzie wysiłku. Ponad stuletni podział owocował m.in. prozelityzmem i ponownym wyświęcaniem duchownych przechodzących z jednego Kościoła do drugiego. Z dzisiejszej perspektywy takie działania jawią się nieuprawnionymi. Mimo że $w$ roku 1897 prymat papieski i nieomylność biskupa Rzymu nie były przyczyną podziału, to z czasem $\mathrm{w}$ obydwu Kościołach powstały różnice $\mathrm{w}$ ich interpretacji. Polski Narodowy Kościół Katolicki na przestrzeni swego istnienia rozwinął silne poczucie własnej tożsamości i niezależności przejawiającej się choćby w doniosłej roli świeckich w zarządzaniu Kościołem. Osiągnięcia jedności nie przyspiesza również fakt, że sporą część duchownych PNKK stanowią byli księża rzymskokatoliccy.

Z drugiej strony, PNKK, opuszczając Unię Utrechcką, której członkiem był przez długie lata, dał wyraz swej niezgodzie na liberalne zmiany zachodzące w niektórych Kościołach starokatolickich. Chodzi tu głównie o wyświęcanie kobiet oraz stosunek do homoseksualizmu. Podobne wydarzenia mają miejsce $\mathrm{w}$ niektórych Kościołach Wspólnoty Anglikańskiej, jak choćby w Kościele Episkopalnym w Stanach Zjednoczonych, z którym PNKK pozostawał od lat trzydziestych XX w. w interkomunii zerwanej jednostronnie $w$ latach siedemdziesiątych, gdy episkopalianie (jako pierwsi wśród anglikanów) zaczęli ordynować kobiety na księży. W obliczu tych wydarzeń PNKK zdaje się akcentować rolę tradycji i katolickiej spuścizny, czego konsekwencją są postępy w zbliżeniu z Kościolem rzymskokatolickim.

„Deklaracja na rzecz jedności" stwierdza konieczność podjęcia dalszego wysiłku w rozwiązywaniu konkretnych kwestii, takich jak: wzajemność w udzielaniu sakramentów, występowanie wiernych jako rodziców chrzestnych w drugim Kościele, małżeństwa mieszane. Starannego namysłu wymagają problemy prymatu papieskiego i synodalności. Autorzy „Deklaracji" nie wypowiadają się autorytatywnie w imieniu swoich Kościołów. W zakończeniu dokumentu wyrażają oni nadzieję na to, że uda im się zaproponować dalsze konkretne działania na rzecz dojrzewającej jedności PNKK i Kościoła rzymskokatolickiego w USA. Zapewniają oni o swym przekonaniu, iż można znaleźć drogę przezwyciężenia "godnego pożałowania podziału, który wydarzył się wśród katolików w Stanach Zjednoczonych". 
By do tego doszło, twórcy dokumentu proszą swych wiernych o gorąca modlitwę, by „wraz z nowym wylaniem Ducha Świętego upadły bariery pomiędzy nami i byśmy niebawem znaleźli się w doskonałej jedności, która wypada uczniom naszego Pana, Jezusa Chrystusa". 